\title{
The Growth of FHIA-17 Banana Seedlings with Application of Hijauan Paitan Fertilizer (Titonia diversifolia) and Cow Manure
}

\author{
Suswati $^{1}$, Asmah Indrawaty ${ }^{2}$, Rizal Aziz $^{3}$, Eka Prasaditya Ramadhani ${ }^{4}$ \\ ${ }^{1,2,3}$ Medan Area University, Medan, Indonesia \\ ${ }^{4}$ Alumni Faculty of Agriculture, Medan Area University, Medan, Indonesia \\ suswati@uma.ac.id
}

\begin{abstract}
Growth of FHIA-17 Banana Seedlings with the Application of Hijauan Paitan Fertilizer (Titonia Diversifolia) and Cow Manure. The aim of this study was to obtain data on the growth of FHIA-17 banana seedlings after application of T.diversifolia forage and cow manure. Using a factorial Randomized Block Design (CRD) with two treatment factors. The first factor is the forage dose of T. diversifolia $(P)$ with 5 levels, $P 0=$ Control; $P 1=12.5 \mathrm{~g} \mathrm{~kg}^{-1}$ planting medium (equivalent to 5 tons $\mathrm{ha}^{-1}$ ); $P 2=25 \mathrm{~g} \mathrm{~kg}^{-1}$ planting medium (equivalent to 10 tons $\mathrm{ha}^{-1}$ ); P3=37.5 $\mathrm{g} / \mathrm{kg}$ of planting media (equivalent to 15 tons $\mathrm{ha}^{-1}$ ); P4=50 $\mathrm{g} \mathrm{kg}^{-1}$ of growing media (equivalent to 20 tons $\mathrm{ha}^{-1}$ ). The second factor is the dose of cow manure $(K)$ with 5 treatment levels namely, $K O=C$ Control; $P 1=12.5 \mathrm{~g} \mathrm{~kg}^{-1}$ of growing media (equivalent to 5 tons $\mathrm{ha}^{-1}$ ); K2=25 $\mathrm{g} \mathrm{kg}^{-1}$ of growing media (equivalent to 10 tons $\mathrm{ha}^{-1}$ ); K3= $37.5 \mathrm{~g} \mathrm{~kg}^{-1}$ of growing media (equivalent to 15 tons $\mathrm{ha}^{-1}$ ); K4=50 $\mathrm{g} \mathrm{kg}^{-1}$ planting medium (equivalent to 20 tons $\mathrm{ha}^{-1}$ and repeated 2 (two) times. Observed parameters were plant height (cm), number of leaves, stem circumference $(\mathrm{mm})$, plant wet weight $(\mathrm{g})$, plant dry weight $(\mathrm{g})$. The results of this study indicate that the application of forage T. diversifolia significantly affected plant height and number of leaves. It's not real with respect to all observational parameters.
\end{abstract}

Keywords: Banana FHIA-17 seeds; Tithonia diversifolia; cow manure; plant height; number of leaves.

\section{Introduction}

Banana is a type of carbohydrate-producing fruit whose production ranks third after mangoes and durian. Indonesia has the potential to become the largest banana producing country in ASEAN because Indonesia has many advantages including almost all locations can be planted with bananas, soil is generally fertile and the high diversity of banana species owned by Indonesia. Indonesia has 250 types of bananas, including Kepok Banana, Raja Banana and Jackfruit. In addition to local bananas, several types of introduced bananas (types of bananas imported from other countries) also began to be planted in Indonesia. This is done because the type of introduced banana is high in production.

FHIA17 bananas (Hondurena de Investigacion Agricola) are a group of table bananas originating from Honduras in Central America. FHIA-17 has been distributed to more than 50 countries for agronomic evaluation and pests and diseases in the International Moses Testing Program (IMTP) (Alvarez, 2008). The FHIA17 cultivar has a high production of $36.5 \mathrm{~kg} /$ plant and cv. FHIA 23 has a weight of $25.0 \mathrm{~kg}$ compared to local cultivars such as cv. Kisukari, Uganda, Embwailuma, Mshale and Jamaica have a higher production weight of 13.7, 15.6, $16.1,16.6$ and $16.8 \mathrm{~kg}$ (Msogoya et al, 2006). In several FHIA 17 testing locations in North Sumatra, higher production was obtained. Planting trials in the low lands of Sampali Village (12 m dpl) production reached $35 \mathrm{~kg} /$ plant, in the medium lands, Lau Sambo $( \pm 350-600$ mdpl) reaching 45-55 kg/bunch and in the highlands (Parapat, $910 \mathrm{~m} \mathrm{dpl}$ ) weight bunches reaching $40 \mathrm{~kg} / \mathrm{plant}$ (Suswati et al, unpublish). 
For large-scale planting seeds are needed in large numbers, uniform and healthy. The efforts can be done to increase production through propagation by tissue culture in vitro. Propagation of plants in vitro can increase the availability of large numbers of plant seeds in a relatively short time, the plants produced have the same properties as the parent and are not affected by the season (Wattimena, 1992).

In addition to using seeds from tissue culture, the growth of FHIA 17 banana seeds needs to be given additional organic materials such as livestock compost and Paitan Hijauan. Paitan (Tithonia diversifolia) is Gulma Tahunan that can be used as a nutrient source for banana plants (Opala et al. 2009, Crespo et al. 2011). The superiority of Paitan plant is that it has a high nutrient content, especially N, P and K. Availability in abundance in the field and can grow in the highlands, fast growth because it can be propagated vegetatively through cuttings and generatively through seeds, the amount of Paitan biomass is 11.3 tons/ha/yr. Paitan Hijau 's decomposed plant tissue can be used as green manure, liquid organic fertilizer and compost (Muhsanati et al. 2008, Hakim et al. 2012) and mulch (Liasu and Achakzai 2007, Adeniyan et al. 2008).

Cow compost is the result of decomposition of cattle solid waste in the form of a mixture of solid manure, urine and residual animal feed. Manure originating from cow dung is good for improving fertility, physical, chemical and biological soil properties, increasing macro and micro nutrients, increasing water holding capacity and increasing cation exchange capacity (Hadis Umitro, 2002).

The advantages of using compost from cow manure ingredients are, it has a high nutrient content such as $\mathrm{N}(0.65 \%), \mathrm{P}(0.15 \%)$ and $\mathrm{K}(0.30 \%)$, the source of material used is waste from cow dung which has not been utilized, the source of material is easily obtained from cattle farmers around the village of Sampali and also the production of manure produced from every 1 cow reaches $23.59 \mathrm{~kg}$.

Based on the description above, research has been conducted which aims to obtain data on the banana seeds growth cv.FHIA 17 seedlings which are applied to compost cattle and Hijauan Paitan.

\section{Research Method}

The research was carried out in the experimental farm of the Faculty of Agriculture and the Laboratory of Agrotechnology study program, Medan Area University, starting from February to July 2018.

\section{Experimental design}

The design used in this study was a Factorial Randomized Block Design (CRD) with two treatment factors. 1) Tithonia diversifolia Green Fertilizer treatment consists of five levels of treatment namely, $\mathrm{P} 0=$ control; $\mathrm{P} 1=12.5 \mathrm{~g} / \mathrm{kg}$ of planting media (equivalent to 5 tons ha- 1 ); $\mathrm{P} 2=25 \mathrm{~g} / \mathrm{kg}$ of planting media (equivalent to 10 tons ha- 1 ); P3 $=37.5 \mathrm{~g} / \mathrm{kg}$ of growing media (equivalent to 15 tons ha-1); P4 = 50 g/kg of growing media (equivalent to 20 tons ha-1); and 2) Compost treatment for cattle cages consists of 5 levels of treatment namely, $\mathrm{K} 0=$ control; $\mathrm{K} 1=12.5 \mathrm{~g} / \mathrm{kg}$ of planting media (equivalent to 5 tons ha- 1 ); $\mathrm{K} 2=25 \mathrm{~g} / \mathrm{kg}$ of growing media (equivalent to 10 ton ha-1); $\mathrm{K} 3=37.5 \mathrm{~g} / \mathrm{kg}$ of planting media (equivalent to 15 tons ha- 1 ); $\mathrm{K} 4$ $=50 \mathrm{~g} / \mathrm{kg}$ of planting media (equivalent to 20 tons ha-1) and repeated in 2 (two ) times. The 
parameters observed in this study were: plant height $(\mathrm{cm})$, number of leaves, stem circumference $(\mathrm{cm})$, plant wet weight $(\mathrm{g})$, plant dry weight $(\mathrm{g})$.

\section{Preparation for FHIA 17 Banana Plantlets and Planting Seeds}

Planlet banana used is cv.FHIA 17, the result of in-vitro propagation from a private tissue culture company, Medan. Banana plantlets are removed from the bottle, washed with running water until the media does not stick, then dried. To stimulate root formation, plantlet roots were cut until only $2 \mathrm{~cm}$. The Barangan plantlet is acclimatized on the mixed media of husk charcoal with sterile sand (2: 1). The mixture is put into a $12 \times 15 \mathrm{~cm}$ size poly bag, then the banana plantlet is individually climatised in each polybag. The poly bag containing FHIA $17 \mathrm{cv}$ plantlet is placed on a wooden shelf, to keep it moist, the seeds are covered with transparent plastic with $60 \%$ lighting. 14-day-old banana seedlings are transferred into a poly bag sized $30 \times 40 \mathrm{~cm}$ containing $8 \mathrm{~kg}$ of soil mixture, Hijauan Paitan and livestock compost according to treatment. Watering the seeds is done every day with $200 \mathrm{ml}$ of tap water. Weeding and pest control is done mechanically.

\section{Maintenance}

Maintenance of bv cv.FHIA 17 seeds is carried out by watering and weeding Gulma. Watering is done once a day at 08.00-09.00 in the morning with a volume of $100 \mathrm{~mL} /$ plant for all treatments and if there is weed growth then weeding is done once a week for 2 months.

\section{Observation}

Observations were made on plant height, bunch of leaves, stem diameter and seedling dry weight.

\section{Results and Discussion}

\section{Plant height}

Plant height was used as an indicator of the growth of bananas cv FHIA 17. Application of Hijauan Paitan and cattle compost at all treatment doses gave results that were not significantly different from controls. Based on observations starting at planting up to 8 weeks after planting (MST), it was found that there were differences in the rate of increase in seedling height with compost application starting at a dose of 5 tons ha-1-20 tons ha-1 and the dose of Hijauan Paitan for all treatment doses compared to control (Table 1). The high growth rate of FHIA17 cv banana seedlings in a single factor P1-P5 with the highest growth rate at factor P5 with a growth rate value of $70.70 \%$. While the single factor K1-K5 the highest growth rate at $\mathrm{K} 280.40 \%$ and the combination of $\mathrm{P}$ and $\mathrm{K}$ the highest growth rate at $\mathrm{P} 2 \mathrm{~K} 4$ factor with a value of $94.90 \%$.

Table 1. Evenly high bv cv.FHIA 17 seedlings and high rate of increase after application of paitan forage ( $\mathrm{T}$. diversifolia) and compost for cattle sheds at the age of 0-8 mst

\begin{tabular}{clllll}
\hline Treatment & $\begin{array}{l}\text { Average } \\
\text { Plant height } \\
(\mathrm{cm})\end{array}$ & $\begin{array}{c}\text { Average Plant } \\
\text { height } \\
\text { increase }\end{array}$ & Treatment & $\begin{array}{c}\text { Average plant } \\
\text { height }(\mathrm{cm})\end{array}$ & $\begin{array}{c}\text { Average Plant } \\
\text { height increase }\end{array}$ \\
\hline P0K0 & 24.50 tn & 55.20 & P2K3 & $25.25 \mathrm{tn}$ & 85.30 \\
P0K1 & 23.25 tn & 63.70 & P2K4 & $25.50 \mathrm{tn}$ & 94.90 \\
P0K2 & 24.50 tn & 80.40 & P3K0 & $27.00 \mathrm{tn}$ & 77.60
\end{tabular}




$\begin{array}{lllllr}\text { P0K3 } & 26.50 \text { tn } & 74.00 & \text { P3K1 } & 25.35 \text { tn } & 84.40 \\ \text { P0K4 } & 23.90 \text { th } & 66.00 & \text { P3K2 } & 29.15 \text { tn } & 1.40 \\ \text { P1K0 } & 23.75 \text { tn } & 53.40 & \text { P3K3 } & 26.25 \text { tn } & 87.60 \\ \text { P1K1 } & 23.25 \text { tn } & 74.40 & \text { P3K4 } & 29.00 \text { tn } & 1.14 \\ \text { P1K2 } & 23.00 \text { tn } & 63.90 & \text { P4K0 } & 25.75 \text { th } & 70.70 \\ \text { P1K3 } & 23.25 \text { tn } & 79.80 & \text { P4K1 } & 23.60 \text { tn } & 76.40 \\ \text { P1K4 } & 23.85 \text { tn } & 67.90 & \text { P4K2 } & 26.00 \text { tn } & 78.50 \\ \text { P2K0 } & 23.65 \text { tn } & 70.20 & \text { P4K3 } & 28.50 \text { th } & 88.80 \\ \text { P2K1 } & 23.75 \text { tn } & 79.20 & \text { P4K4 } & 29.00 \text { tn } & 1.40 \\ \text { P2K2 } & 25.00 \text { tn } & 70.20 & & & \end{array}$

The mean height of seedlings cv. FHIA 17 was not significantly different for all treatments, but the value of the high rate of increase was different. The difference in the rate of increase in seedling height was caused by the ability to absorb different nutrients in each plant. The higher the dose of organic matter is given, the faster it will improve the development of organs such as roots, so that plants can absorb more nutrients and water in the soil which will further affect the height of banana seeds. However, plants also have a certain limit in absorbing nutrients. Lakitan (1993) said that the differences in the rate of height increase and the unequal meristematic tissue activity caused differences in the rate of formation of organs which were not the same, such as the formation of organs in leaves, stems and other organs.

\section{Stem diameter}

Growth rate of banana seedling stem diameter cv.FHIA-17 on a single factor P1-P5 with the highest growth rate on factor P1 with a growth rate value of $53.4 \%$. While the single factor $\mathrm{K} 1-\mathrm{K} 5$ the highest growth rate at $\mathrm{K} 3$ is $49.9 \%$ and the combination of $\mathrm{P}$ and $\mathrm{K}$ is the highest growth rate at the $\mathrm{P} 3 \mathrm{~K} 2$ factor with a growth rate value of $70.1 \%$.

Table 2. Average diameter of stem banana cv. FHIA 17 at age $0-8$ mst and rate of increase in stem diameter after application of hijaun paitan fertilizer (T. diversifolia) and livestock compost.

\begin{tabular}{ccclcc}
\hline Treatment & $\begin{array}{l}\text { Average } \\
\text { stem } \\
\text { diameter } \\
(\mathrm{cm})\end{array}$ & $\begin{array}{c}\text { Rate of } \\
\text { increment of } \\
\text { stem diameter }\end{array}$ & Treatment & $\begin{array}{l}\text { Average } \\
\text { stem } \\
\text { diameter } \\
(\mathrm{cm})\end{array}$ & $\begin{array}{c}\text { Rate of } \\
\text { increment of } \\
\text { stem } \\
\text { diameter }\end{array}$ \\
\hline P0K0 & $7.10 \mathrm{tn}$ & 30.80 & P2K3 & $8.50 \mathrm{tn}$ & 44.80 \\
P0K1 & $8.00 \mathrm{tn}$ & 40.40 & P2K4 & $8.15 \mathrm{tn}$ & 45.50 \\
P0K2 & $8.15 \mathrm{tn}$ & 46.30 & P3K0 & $8.25 \mathrm{tn}$ & 41.70 \\
P0K3 & $8.50 \mathrm{tn}$ & 49.90 & P3K1 & $8.85 \mathrm{tn}$ & 45.40 \\
P0K4 & $7.60 \mathrm{tn}$ & 35.00 & P3K2 & $10.35 \mathrm{tn}$ & 70.10 \\
P1K0 & $7.60 \mathrm{tn}$ & 53.40 & P3K3 & $8.40 \mathrm{tn}$ & 44.20 \\
P1K1 & $7.75 \mathrm{tn}$ & 44.40 & P3K4 & $9.95 \mathrm{tn}$ & 68.50 \\
P1K2 & $8.10 \mathrm{tn}$ & 45.40 & P4K0 & $8.25 \mathrm{tn}$ & 39.30 \\
P1K3 & $7.95 \mathrm{tn}$ & 48.60 & P4K1 & $7.90 \mathrm{tn}$ & 45.80 \\
P1K4 & $7.75 \mathrm{tn}$ & 32.90 & P4K2 & $8.05 \mathrm{tn}$ & 41.00 \\
P2K0 & $7.40 \mathrm{tn}$ & 37.40 & P4K3 & $9.30 \mathrm{tn}$ & 53.90 \\
P2K1 & $7.45 \mathrm{tn}$ & 36.30 & P4K4 & $9.80 \mathrm{tn}$ & 58.20 \\
P2K2 & $7.80 \mathrm{tn}$ & 40.40 & & & \\
\hline
\end{tabular}


An increase in the diameter of the FHIA 17 seedling stem is closely related to the nutrient content in Paitan network. According to the research by Purwani (2011), Paitan contains $2.7-3.59 \% \mathrm{~N} ; 0.14-0.47 \% \mathrm{P}$; and $0.25-4.10 \% \mathrm{~K}$, so that the administration of Paitan compost can increase the diameter of the seedling stem cv. FHIA 17. This is consistent with the results of the research of Hakim et al (1986), that Paitan as an organic material is a source of plant nutrients and can increase the solubility of the elements $\mathrm{P}, \mathrm{K}$, Cadan $\mathrm{Mg}$, and Corganic, cation exchange capacity, and water absorption. Besides the addition of organic matter will also increase the ability to hold water so that it can provide water in the soil for plant growth (Atmojo (2003).

\section{Number of Leaves}

The average number of leaves of banana seedlings cv. FHIA 17 ranges from 6.5 strands to 10 strands with a rate of increase in the number of leaves $29.70 \%-86.90 \%$. The lowest leaf growth rate was in the P1K3 treatment and the highest was in the P2K3 treatment (Table 3).

Application of 15 tons of manure ha- 1 combined with a dose of 10 tons of ha-1 is the best treatment in increasing the rate of increasing the number of leaves with an average number of leaves 8.50. This is consistent with the results of research by Hadisuwito, (2012) where an increase in the number of leaves is closely related to the presence of Nitrogen $(\mathrm{N})$ in both types of organic material sources needed for the formation or vegetative growth of plants such as height, leaves, stems and roots of plants.

Table 3. Average number of banana seedlings cv. FHIA 17 at age $0-8 \mathrm{mst}$ and rate of leaf growth after application of paitan green fertilizer ( $\mathrm{T}$. diversifolia) and animal compost.

\begin{tabular}{ccclcc}
\hline Treatment & $\begin{array}{l}\text { Average } \\
\text { number of } \\
\text { leaves }(\mathrm{cm})\end{array}$ & $\begin{array}{c}\text { The rate of } \\
\text { increase in the } \\
\text { number of } \\
\text { leaves }\end{array}$ & Treatment & $\begin{array}{l}\text { Average } \\
\text { number of } \\
\text { leaves }(\mathrm{cm})\end{array}$ & $\begin{array}{c}\text { The rate of } \\
\text { increase in the } \\
\text { number of } \\
\text { leaves }\end{array}$ \\
\hline P0K0 & $8.00 \mathrm{tn}$ & 52.90 & P2K3 & $8.50 \mathrm{tn}$ & 86.90 \\
P0K1 & $7.50 \mathrm{tn}$ & 45.80 & P2K4 & $8.50 \mathrm{tn}$ & 63.60 \\
P0K2 & $8.00 \mathrm{tn}$ & 61.90 & P3K0 & $8.00 \mathrm{tn}$ & 44.00 \\
P0K3 & $8.00 \mathrm{tn}$ & 51.70 & P3K1 & $8.00 \mathrm{tn}$ & 49.40 \\
P0K4 & $8.50 \mathrm{tn}$ & 58.90 & P3K2 & $8.50 \mathrm{tn}$ & 55.90 \\
P1K0 & $7.50 \mathrm{tn}$ & 52.30 & P3K3 & $9.50 \mathrm{tn}$ & 73.80 \\
P1K1 & $8.00 \mathrm{tn}$ & 57.70 & P3K4 & $9.50 \mathrm{tn}$ & 68.40 \\
P1K2 & $9.00 \mathrm{tn}$ & 66.60 & P4K0 & $7.50 \mathrm{tn}$ & 47.00 \\
P1K3 & $6.50 \mathrm{tn}$ & 29.70 & P4K1 & $7.50 \mathrm{tn}$ & 52.30 \\
P1K4 & $7.50 \mathrm{tn}$ & 45.20 & P4K2 & $8.00 \mathrm{tn}$ & 38.10 \\
P2K0 & $8.50 \mathrm{tn}$ & 68.40 & P4K3 & $7.50 \mathrm{tn}$ & 40.40 \\
P2K1 & $8.00 \mathrm{tn}$ & 51.10 & P4K4 & $10.00 \mathrm{tn}$ & 79.70 \\
P2K2 & $8.50 \mathrm{tn}$ & 54.70 & & & \\
\hline
\end{tabular}

\section{Dry weight of banana seeds}

Application of paitan green fertilizer ( $T$. diversifolia) did not have a significant effect on the dry weight of FHIA17 banana seeds. In the application of paitan green fertilizer (T. diversifolia) treatment showed that the highest dry weight of the plant was in the treatment of P3 with an average of $84.72 \mathrm{~g}$ also the application of cow manure did not have a significant effect on the dry weight of FHIA-17 banana seeds. In the treatment of cow manure application 
shows that the highest dry weight of the plant is in the K0 treatment with an average of 85.22 g. Application of combination treatment from the application of paitan green fertilizer ( $\mathrm{T}$. diversifolia) and cow manure showed the highest dry weight, namely the P4K2 treatment with an average of 85.25. From each plant dry weight shown in each treatment has not shown a significant effect on the dry weight of FHIA-17 banana seedlings (Table 4).

Table 4. Average dry weight of banana seedlings cv. FHIA 17 at age 0-8 mst and rate of dry weight gain after application of paitan green fertilizer (T.diversifolia) and livestock compost.

\begin{tabular}{cccccc}
\hline Treatment & $\begin{array}{c}\text { Average dry } \\
\text { weight }(\mathrm{g})\end{array}$ & $\begin{array}{c}\text { Effectiveness } \\
(\%)\end{array}$ & Treatment & $\begin{array}{c}\text { Average dry } \\
\text { weight }(\mathrm{g})\end{array}$ & Effectiveness (\%) \\
\hline P0K0 & 86.92 & - & P2K3 & 80.81 & -7.02 \\
P0K1 & 75.68 & -12.93 & P2K4 & 85.48 & -1.65 \\
P0K2 & 84.76 & -2.48 & P3K0 & 84.71 & -2.54 \\
P0K3 & 83.66 & -3.75 & P3K1 & 82.85 & -4.68 \\
P0K4 & 85.20 & -1.97 & P3K2 & 85.64 & -1.47 \\
P1K0 & 83.21 & -4.26 & P3K3 & 85.84 & -1.24 \\
P1K1 & 80.83 & -7.00 & P3K4 & 84.59 & -2.68 \\
P1K2 & 80.18 & -7.75 & P4K0 & 86.78 & -0.16 \\
P1K3 & 81.12 & -6.67 & P4K1 & 82.10 & -5.54 \\
P1K4 & 84.76 & -2.48 & P4K2 & 88.25 & 1.53 \\
P2K0 & 84.50 & -2.78 & P4K3 & 83.50 & -3.93 \\
P2K1 & 77.66 & -10.65 & P4K4 & 81.07 & -6.73 \\
P2K2 & 81.14 & -6.64 & & & \\
\hline
\end{tabular}

According to Simatupang's research results (2014) for the dose of Paitan compost (Tithonia diversifolia) given at a dose of 20 tons ha- 1 can increase plant height, growth rate of number of leaves and leaf dry weight in cauliflower plants. Onion compost 30 tons ha- 1 manure can increase tuber weight, number of crop leaves and total dry weight per plant which significantly influence the dry weight of tubers per hectare (Mayun, 2007). According to Lestari (2016) Paitan compost is considered suitable as a source of organic fertilizer because it contains relatively high $\mathrm{N}, \mathrm{P}$, and $\mathrm{K}$ nutrients as well as beneficial for environmental improvement. Paitan compost in addition to containing N, P, and K nutrients the administration of paitan compost can increase $\mathrm{pH}$, decrease $\mathrm{Al}$-dd and increase $\mathrm{Ca}$ and $\mathrm{Mg}$ nutrient content in the soil (Hartatik, 2007).

\section{Conclusion}

Based on the results of this study it can be concluded that Hijauan Paitan organic material and cow cage compost at various doses affect the growth of banana seeds cv. FHIA 17. The application of 15 tons of manure combined with Paitan dosage of 10 tons ha-1 (P2K3) is the best treatment in increasing the rate of increase in leaf number and treatment (P4K2) gave the highest dry weight, the highest stem diameter was found in Paitan treatment of 15 tons ha-1 and a compost dose of 5 tons ha-1 (P3K2). 


\section{References}

Hadisumitro, L.M. 2002. Membuat Kompos. Penebar Swadaya. Jakarta.

Hartatik, W. 2007. Tithonia diversifolia sebagai Pupuk Hijau. Warta Penelitian dan Pengembangan Pertanian Vol. 29(5):3-5.

Njuguna, J, Nguthi, F. Wepukhulu, S. Wambugu, F, Gitau, D, Karuoya.M And Karamura.D. 2008. Introduction And Evaluation of Improved Banana Cultivars For Agronomic and Yield Characteristics In Kenya. African Crop Science Journal, Vol. 16, No. 1, 35 - 40.

Lakitan. 1993. Dasar-dasar Fisiologi Tumbuhan. PT Raja Grafindo Persada.Jakarta

Lestari, S.A.D. 2016. Pemanfaatan Paitan (Tithonia diversifolia) sebagai Pupuk Organik pada Tanaman Kedelai. Iptek Tanaman Pangan Vol. 11(1)

Msogoya, T.J , A.P. Maerere, P.M. Kusolwa and L.T. Nsemwa, 2006. Field Performance of Improved Banana Cv. Fhia 17 and Fhia 23 in the Eastern Zone of Tanzania. Journal of Agronomy, 5:533-535.

Mayun, I.A. 2007. Efek Mulsa Jerami Padi dan Pupuk Kandang Sapi terhadap Pertumbuhan dan Hasil Bawang Merah di Daerah Pesisir. Jurusan Budidaya Pertanian Fakultas Pertanian, Universitas Udayana. Bali. Agritrop, Vol. 26, No. 1

Purwani, J. 2011. Pemanfaatan Tithonia diversifolia (Hamsley) A. Gray untuk perbaikan tanah. Balai Penelitian Tanah. 253-263.

Simatupang, P. 2014. Pengaruh Dosis Kompos Paitan (Tithonia difersifolia) terhadap Pertumbuhan dan Hasil Kol Bunga Pada Sistem Pertanian Organik.Skripsi. Fakultas Pertanian. Universitas Bengkulu.

Wattimena, 1992, Zat Pengatur Tumbuh Tanaman, Pusat Antar Universitas (PAU) Bioteknologi Insitut Pertanian Bogor 